Original Research Paper

\title{
Revitalisasi Moral Generasi Muda dan Penekanan Angka Pernikahan Dini Melalui Sosialisasi Penguatan Nilai-Nilai Agama Dan Budaya Di Desa Bagik Payung Timur, Lombok Timur
}

\author{
LL. Abd. Muhyi Abidin ${ }^{1 *}$ Lale Yaqutunnafis², Bukhori Muslim³, Agil Al Idrus ${ }^{4}$, Liwa \\ Ilhamdi $^{5}$, Pahmi Husain ${ }^{6}$ \\ ${ }^{1}$ Program Studi Bahasa Inggris, Fakultas Keguruan dan Ilmu Pendidikan, Universitas Nahdlatul \\ Wathan Mataram, Indonesia \\ ${ }^{2}$ Program Studi Pendidikan Ekonomi, Fakultas Keguruan dan Ilmu Pendidikan, Universitas \\ Nahdlatul Wathan Mataram, Indonesia \\ ${ }^{3}$ Program Studi Pendidikan Bahasa Indonesia, Fakultas Keguruan dan Ilmu Pendidikan, \\ Universitas Nahdlatul Wathan Mataram, Indonesia \\ ${ }^{4,5}$ Program Studi Pendidikan Biologi Jurusan Fakultas Keguruan dan Ilmu Pendidikan, \\ Universitas Mataram, Indonesia \\ ${ }^{6}$ Program Studi Biologi, Fakultas Matematika dan Ilmu Pengetahuan Alam, Universitas \\ Nahdlatul Wathan Mataram, Indonesia
}

https://doi.org/10.29303/jpmpi.v3i2.997

Sitasi: Abidin, LL. A. M., Yaqutunnafis, L., Muslim, B., Idrus, A. A., Ilhamdi, L \& Husain, P. (2021). Pemanfaatan Ikan Tuna Menjadi Siomay untuk Meningkatkan Pendapatan Keluarga. Jurnal Pengabdian Magister Pendidikan IPA, 4(4)

\section{Article history}

Received: 15 September 2021

Revised: 20 September 2021

Accepted: 25 September 2021

*Corresponding Author: LL. Abd.

Muhyi Abidin, Program Studi

Ilmu Alqur'an dan Tafsir,

Fakultas Agama Islam,

Universitas Nahdlatul Wathan

Mataram, Indonesia;

Email:

abdmuhyiabidin@unwmataram.ac.id

\begin{abstract}
Abstrak:
Kondisi moral generai muda di tengah tantangan kemajuan teknologi dan informasi menjadi perhatian semua pihak. Penguatan nilai-nilai moral dan budaya menjadi alternatif usaha yang dapat dilakukan dalam menjaga kualitas moral dan penekanan angka pernikahan dini yang marak terjadi di tengah kehidupan masyarakat. Metode yang digunakan adalah penyuluhan berupa sosialisasi, diskusi, Tanya jawab. Hasil Pengabdian menunjukkan bahwa semua peserta yang hadir sangat antusias mengikuti kegiatan pengabdian yaitu sosialisasi, diskusi dan Tanya jawab mengenai uapayaupaya yang dapat dapat dilakukan untuk meningkatkan pemahaman terkait moral anak muda dan langkah-langkah yang dapat dikerjakan oleh semua pihak agar dapat menekan angka pernikahan dini yang ada di Desa Bagik Payung Timur, Kecamatan Suralaga, Lombok Timur. Kesimpulan kegiatan pengabdian sebagai berikut: semua peserta yang terdiri dari pemuda, tokoh agama dan masyarakat maupun orang tua sangat antusias mengikuti seluruh rangkaian kegiatan dan memberikan respon yang positif selama kegiatan pengabdian berlangsung. Tim Pengabdian memaparkan dan memberikan sosialisasi upaya penguatan moral dengan menginternalisasikan nilai-nilai agama dan budaya. Kemudian peserta yang menghadiri kegiatan sosialisasi secara pro-aktif menanyakan hal-hal yang belum jelas dari materi sosialisasi yang telah disampaikan. Pada akhir kegiatan ini peserta sosialisasi memperoleh pengetahuan dan wawasan yang baik tentang revitalisasi moral generasi muda dan upaya penekanan angka pernikahan di bawah umur melalui penguatan nilai-nilai agama dan budaya di Desa Bagik Payung Timur Kecamatan Suralaga, Lombok Timur.
\end{abstract}

Keywords: Moral, Generasi Muda, Pernikahan Dini, Nilai-nilai Agama dan Budaya 


\section{Pendahuluan}

Dermasalahan moral generasi muda menjadi isu yang penting untuk dikaji dan carikan solusinya. Karena tantangan zaman yang dibarengi dengan kemajuan teknologi 4.0 di beberapa tahun terakhir cukup berdampak signifikan terhadap kemerosotan dan degradasi moral generasi muda. Sementara pemuda adalah generasi penerus dan harapan bangsa yang masa depan bangsa kedepan akan sangat ditentukan oleh kualitas generasi muda (Sunarso, 2020). Salah satu indikasi yang menyebabkan lunturnya moral generasi muda adalah kemerosatan akhlak seperti pergaulan seks bebas, tauran antar kelompok remaja, bahkan penyalahgunaan obat-obat terlarang, pornografi, perkosaan dan lain-lain. Fenomena ini menjadi masalah sosial yang belum dapat diatasi di tengah-tengah masyarakat hingga saat ini.

$\begin{array}{cllr}\text { Arus } & \text { globalisasi } & \text { di tengah-tengah } \\ \text { kehidupan } & \text { generasi } & \text { muda } & \text { mampu }\end{array}$
mentranformasikan gaya hidup, passion dan moral anak bangsa secara perlahan-lahan dalam kurun waktu yang relatif singkat. Karena melalui teknologi modern dapat tercipta pola-pola yang instan seperti dapat terciptanya komunikasi lintas negera bahkan benua. Kemudian adanya berbagai platform sosial media berupa IG, Facebook, Twiter dan YouTube menjadi santapan sehari-hari kaum millennial yang jika tidak dipergunakan dengan baik dapat mengubah perilaku belajar, karakter dan menimbulkan candu untuk bermedia sosial secara berlebihan (Anggun, 2013).

Pembangunan karakter dan kepribadian generasi muda harus diformulasikan dengan menggunakan pendekatan-pendekatan yang sederhana dan mudah diterima. Misalnya dengan pendekatan agama dan budaya yang berlaku di sekitarnya. Penguatan nilai-nilai agama dapat dijadikan sebagai salah satu metode untuk membentuk karakter dan moral yang baik pada generasi muda. Karena nilai-nilai agama senantiasa melekat dalam diri setiap individu hanya saja harus dilatih dan dibudayakan tidak hanya di lingkungan sekolah melainkan di lingkungan masyarakat sekitarnya. Proses internalisasi nilai-nilai agama dapat dilakukan mulai dari lingkungan keluarga dengan membiasakan perilaku sopan, jujur dan bertanggung jawab sehingga secara perlahan karakter dan moral generasi muda dapat dibentuk dengan baik sebagai salah satu upaya dalam mengantisipasi degradasi modal generasi muda (Muthohar, 2013).

Pemuda-pemudi yang tinggal di Desa Bagik Payung Timur didominasi oleh anak SMP dan SMA. Kemudian ada juga yang sudah tamat SMA namun tidak dapat melangsungkan pendidikannya ke bangku kuliah. Rendahnya tingkat pendidikan anak muda yang ada di Desa Bagik Payung Timur diakibatkan dukungan dan peran orangtua relatif kurang dalam mengawasi anak-anaknya. Hal ini dapat digambarkan dengan tren anak-anak yang masih sekolah lebih suka bekerja sebagai buruh tambang pasir yang ada di desa Bagik Payung Timur. Akibatnya anak-anak lebih mudah mendapatkan uang secara praktis sehingga kegiatan persekolahannya menjadi terabaikan.

Kelompok pemuda yang ada di desa juga cenderung membuat kelompok dan mengikuti trend perkembangan zaman terutama di arus teknologi informasi yang begitu pesat yang tidak jarang dapat menggeser budaya dan tradisi kultural masyarakat yang sudah berkembang dari masa ke masa. Oleh karena itu, dari fenomena yang sudah dipaparkan di atas perlunya dilakukan penguatan dan pembinaan terhadap kelompok pemuda guna meningkatkan kualitas moral dan menekan angka pernikahan dini bagi generasi muda yang ada di Desa Bagik Payung Timur, Kecamatan Suralaga, Kabupaten Lombok Timur.

\section{Metode}

Metode pelaksanaan kegiatan pengabdian masyarakat ini berfokus pada upaya-upaya yang dapat dilakukan berkaitan dengan peningkatan kualitas moral generasi muda dan penekanan angka pernikahan dini menggunakan pendekatan agama dan budaya yang ada di Desa Bagik Payung Timur. Kendala-kendala yang dihadapi oleh masyarakat dalam menyikapi kemerosotan moral anak muda diatasi dengan sosialisasi revitalisasi moral generasi muda. Metodenya ceramah, diskusi dan tanya jawab. Sosialisasi dilakukan dengan menyampaikan materi/konsep yang dapat diimplementasikan di lingkungan masyarakat khususnya genrasi muda. Peserta sosialisasi yang diundang terdiri dari kelompok karang taruna, perwakilan siswa-siswi SMP dan SMA serta tokoh agama dan masyarakat yang ada di Desa Bagik Payung Timur. 


\section{Hasil dan Pembahasan}

Pembentukan karakter dan moral generasi muda ditentukan oleh banyak faktor. Misalnya lingkungan keluarga, masyarakat maupun lingkungan sekolah. Moral generasi muda yang ada desa seringkali mendapatkan perhatian yang kurang serius. Persoalan karakter dan moral generasi muda semata-mata dikonotasikan dengan tanggung jawab sekolah semata, sehingga tidak sedikit orang tua yang kurang memperhatikan gaya hidup dan kultur anak muda. Sementara itu, anak-anak muda tersebut akan berinteraksi dengan masyarakat dan lingkungan yang lebih kompleks yang ada di luar sekolah. Dalam hal ini pengaruh lingkungan keluarga yang merupakan lingkungan yang paling dekat dengan kehidupan generasi mudah harus diperhatikan dengan fungsi pengawasan dari orang tua. Selain lingkungan keluarga, teman bermain, tetangga dan kelompok pemuda juga akan memberikan pengaruh yang cukup signifikan terhadap pengembangan moral seorang anak (Inawati, 2017).

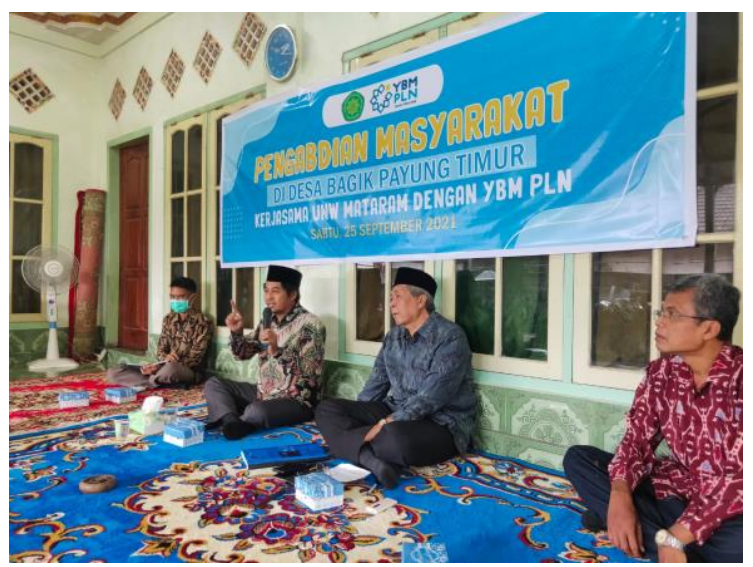

Gambar 1. Penyampaian materi sosialisasi oleh narasumber

\section{a. Penguatan nilai-nilai agama dengan program-program religi dan kekinian}

Penguatan nilai-nilai agama pada kaum muda yang ada di pelosok desa perlu dilakukan secara perlahan dengan pendekatan baru misalnya membuat program-program religi pada komunitas/ kelompok pemuda dengan mendatangkan public figure yang mereka idolakan dan memberikan motivasi dan materi yang tidak terkesan membosankan. Nilai-nilai agama Islam yang melekat pada diri setiap individu juga sebagai sarana yang harus ditanamkan sejak dini dengan contoh-contoh yang konkrit dalam kehidupan sehari-hari seperti melatih kebiasaan jujur, berkata dengan sopan santun, disiplin dan bertanggung jawab dan tidak menyinggung orang lain dengan kata lain berlaku toleransi dan saling menghargai satu sama lain.

\section{b. Peran semua elemen yang ada di masyarakat dalam mengawasi moral dan akhlak generasi muda}

Penguatan nilai-nilai agama di luar sekolah memerlukan usaha yang serius dari berbagai elemen terutama pihak keluarga, tokoh agama, tokoh masyarakat dan pemerintah desa setempat. Elemen-elemen ini harus bekerjasama untuk saling mendukung dalam menyikapi persoalan moral anak muda yang makin lama kian merosot. Penguatan dari aspek budaya dan kearifan lokal juga perlu disosialisasikan agar anak-anak muda dapat meniru dan berperilaku sesuai dengan norma-norma yang sudah berlaku di tengah-tengah masyarakat. Seringkali anak-anak muda merasa terpisahkan dalam kehidupan sosial dengan kelompok yang lebih tua. Sehingga proses transformsi nilai-nilai moral dan budaya menjadi terhambat karena kesenjangan dalam kehidupan sosial masyarakat. Oleh karena itu, untuk menjaga dan meningkatkan kualitas moral anak muda agar berperilaku baik harus diupayakan sejak dini sebelum pergeseran nilai dan norma yang ada pada generasi muda tergerus lebih jauh dan menimbulkan hal-hal yang tidak diharapkan. Berbagai sarana yang dapat dimanfaatkan untuk membina moral anak muda yang ada di desa seperti masjid, mushola, Lembaga-lembaga pendidikan, surat kabar, internet, majalah, televisi, radio dan lain-lain dapat juga digunakan dalam membina moral dengan ukuranukuran dan standarisasi yang berlaku (Suradarma, 2018).

\section{c. Pendidikan karakter sekolah harus disinergikan dengan lingkungan luar sekolah}

Pendidikan karakter yang sudah dicanangkan dalam program pendidikan secara nasional oleh pemerintah perlu disinergikan dengan elemen-elemen yang ada di lingkungan masyarakat. Pendidikan karakter yang diinternalisasikan dalam 
berbagai mata pelajaran sekolah menjadi instrumen pendukung dalam pembentukan moral generasi muda, sehingga ketika berada di luar sekolah, aktivitas anak-anak tidak boleh dilepas oleh orang tua dan masyarakat setempat sehingga anak-anak merasa bebas dalam bersikap dan berperilaku. Untuk itu, pendidikan karakter dapat dilaksanakan mulai dari lingkungan sekolah dengan beberapa strategi di antaranya strategi inklusif yang dapat dilakukan oleh guru, budaya sekolah, serta eksplorasi diri sendiri dan penilaian teman sejawat (Kurniati, 2018). Kemudian ngawasan dari semua pihak untuk mengontrol pergaulan generasi muda di luar sekolah juga perlu ditingkatkan.

\section{d. Upaya penekanan angka pernikahan dini dengan pendekatan agama dan budaya}

Kasus pernikahan dini yang terjadi pada anakanak di bawah umur merupakan fenomena harus ditangai dari lingkungan keluarga. Orang tua sangat berperan penting dalam segela bentuk siklus kehidupan anak. Maraknya kasus pernikahan dini menjadi persoalan yang segera dituntaskan agar kasus pernikahan dini tidak menjadi budaya yang ditiru oleh anak-anak lainnya. Orang tua harus sedapat mungkin mengontrol anak baik di lingkungan keluarga atau di lingkungan luar rumah. Orang tua dapat mengawasi anak agar tidak masuk ke dalam lingkungan tidak kondusif. Orang tua sebaiknya hendaknya memotivasi anak-anaknya agar fokus dalam menyelesaikan pendidikannya baik di bangku SMP, SMA bahkan kuliah. Karena tindakan anak-anak yang menikah di bawah umur merupakan tindakan melanggar UU No.1 Tahun 1974 yang direvisi pada tahun 2019 bahwa usia diperbolehkan anak untuk menikah yaitu anak sudah mencapai umur 19 tahun. Oleh karena itu, orang tua harus menjamin berjalan atau tidak aktivitas persekolahan anak dengan kata lain untuk menekan kasus pernikahan dini, anak-anak jangan sampai putus sekolah. Karena apabila anak-anak berhenti sekolah maka potensi anak-anak untuk menikah di bawah umur cukup tinggi.

Selain itu, pengawasan sosial masyarakat juga sangat diperlukan, karena masyarakat yang berada di luar lingkungan kerluarga dapat mempengaruhi lingkungan pergaulan anak-anak dengan membentuk keteraturan sosial dan budaya. Jika masyarakat mampu menciptakan lingkungan yang baik dimana masyarakat pro-aktif agar tidak menyarankan dan membiarkan anak-anak menikah di bawah umur.

\section{e. Penguatan nilai-nilai agama dan budaya di tengah krisis pandemi covid-19}

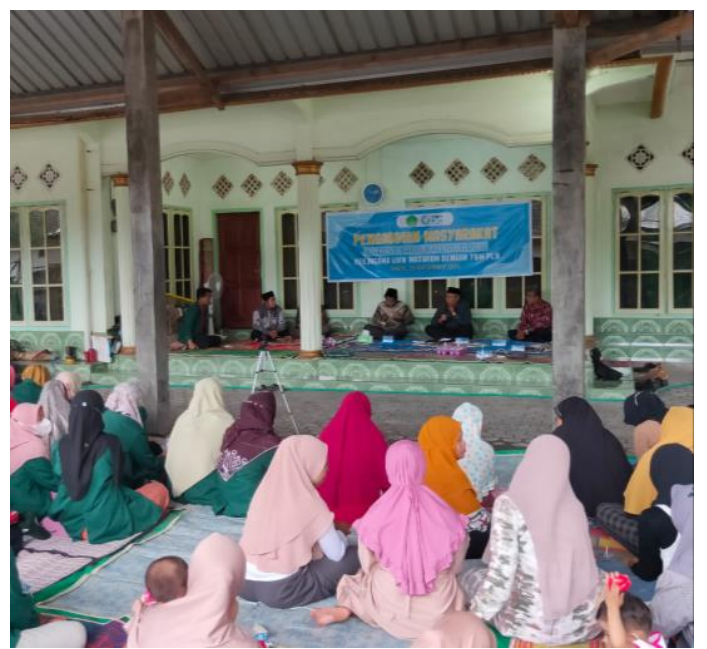

Gambar 2. Peserta menyimak penyampaian materi oleh narasumber

Penguatan nilai-nilai agama dan budaya pada generasi muda yang ada di desa harus menjadi perhatian semua pihak di tengah-tengah krisis pandemi Covid-19. Dimana proses pembentukan karakter melalui kegiatan persekolahan secara tatap muka beralih menjadi pembelajaran dengan metode online (Daring) sehingga ruang untuk mentransformasikan pengetahuan dan perilaku lambat laun menjadi kendor karena pembelajaran langsung digantikan dengan tatap muka yang secara efektifitas dan efisiensi berkurang. Oleh karena itu persoalan moral dan akhlak generasi muda menjadi perhatian yang semua pihak. Agar nilai-nilai dan norma yang ada di masyarakat tetap ditransfer kepada generasi muda di tengah situasi yang kurang menguntungkan akibat pandemi covid- 19 .

Kegiatan diskusi terkait materi yang disampaikan dilakukan diakhir sesi penyanpaian materi dimana peserta yang menghadiri acara tersebut secara bergilir mengutarakan beberapa jumlah pertanyaan yang berkaitan dengan dinamika 
pergaulan anak muda yang cenderung bebas dan kurang fokus dalam kegiatan belajar di sekolah. Dalam kasus ini diperlukan dukungan dan kontrol orangtua karena orang tua sangat berperan dalam mengawal masa depan anak pada masa-masa yang akan datang. Karena generasi muda yang masih menempuh pendidikan sekolah saat ini akan menjadi calon-calon pemimpin masa depan. Sehingga generasi muda yang ada di Desa Bagik Payung Timur harus cerdas secara keilmuan, sosial dan budaya.

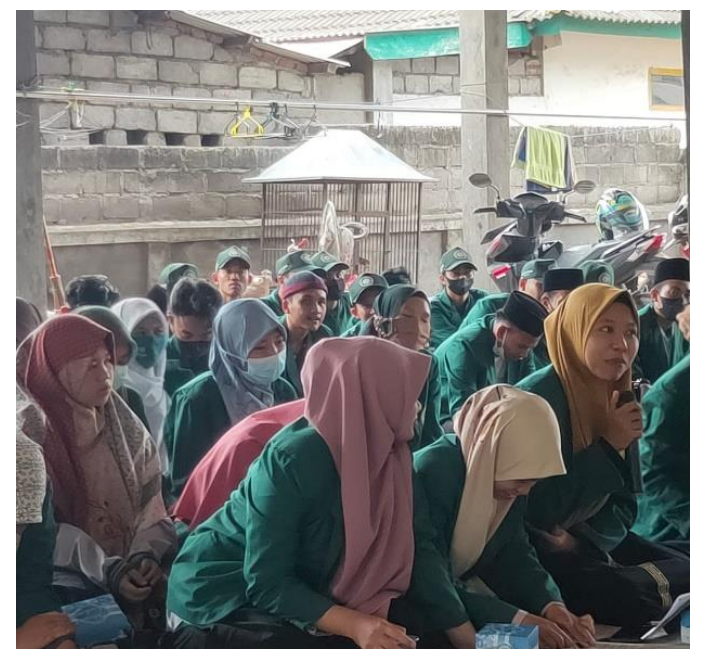

Gambar 3. Kegiatan diskusi dan tanya jawab

Kegiatan focus group discussion/FGD dilakukan setelah narasumber memberikan materi sosialisasi. $70 \%$ peserta yang hadir sangat aktif dalam kegiatan diskusi dan sesi tanya jawab. Beberapa permasalahan yang dihadapi oleh peserta terutama dari kalangan tokoh dan orang tua diutarakan dan dijawab oleh naraumber yang berkaitan dangan upaya dalam menyikapi kemerosotan moral dan akhlak anak-anak muda di tengah kemajuan teknologi dan informasi.

Kegiatan penutup kegiatan sosialisasi diakhir dengan pemberian paket sembako oleh tim pengabdian kepada para peserta yang hadir dalam acara ini. Pemberian paket sembako ini dimaksudkan untuk memotivasi masyarakat khususnya yang terkenda dampak pandemi covid19 yang tengah mengalami kesusahan dalam pemenuhan covid-19. Pemberian paket sembako ini difasilitasi oleh YBM PLM Nusa Tennggara Barat yang bekerja sama dengan tim pengabdian dari Universitas Nahdlatul Wathan yang turut serta mengambil bagian dalam penanggulangan wabah virus corona yang melanda hampir di seluruh wilayah yang ada di Indonesia bahkan manca negara.

\section{Kesimpulan}

Serangkaian kegiatan pengabdian pada masyarakat di Desa Bagik Payung Timur yang telah berlangsung dapat diambil kesimpulan sebagai berikut: semua peserta yang terdiri dari pelajar, pemuda, tokoh agama dan masyarakat maupun orang tua yang ada di Desa Lombok Timur sangat antusias mengikuti seluruh rangkaian kegiatan dengan memberikan respon yang positif selama kegiatan sosialisasi berlangsung. Tim Pengabdian memaparkan dan memberikan sosialisasi upaya penguatan moral dan upaya penekanan angka pernikahan dini dengan menginternalisasikan nilainilai agama dan budaya yang berkembang di tengah masyarakat. Peserta yang hadir cukup aktif menanyakan hal-hal yang belum jelas dari materi sosialisasi yang telah disampaikan. Pada akhir kegiatan ini perserta sosialisasi dapat memperoleh pengetahuan yang baik tentang revitalisasi moral generasi muda dan penekanan angka pernikahan dini melalui penguatan nilai-nilai agama dan budaya yang ada di Desa Bagik Payung Timur Kecamatan Suralaga, Lombok Timur.

\section{Ucapan Terima Kasih}

Tim pengabdian pada masyarakat menyampaikan ucapan terima kasih kepada Universitas Nahdlatul Wathan yang telah memberikan ruang sehingga kegiatan pengabdian pada masyarakat ini. Kemudian Terimakasih juga kepada Yayasan Baitul Maal PLN Wilayah Nusa Tenggara Barat yang telah memberikan bantuan materiil sehingga kegiatan pengabdian ini berjalan dengan lancar.

\section{Daftar Pustaka}

Anggun, G. 2013. Pentingnya Menumbuhkan Pendidikan Moral Di Era Globalisasi, https://goenable.wordpress.com/pent ingnya-menumbuhkan-pendidikanmoral-di-era-globalisasi, diakses tgl 10 September 2021. 
Inawati, A. (2017). Strategi pengembangan moral dan nilai agama untuk anak usia dini." Al-Athfal: Jurnal Pendidikan Anak, 3 (1): 51-64.

Kurniawati, A. 2018. Pendidikan Karakter dengan Pendekatan Berbasis Agama dan Budaya Bangsa. Jurnal Ilmiah Pesantren, 4(2):515-525.

Muthohar, Sofa. 2016. Antisipasi degradasi moral di era global. Nadwa,7(2): 321-334.

Suradarma, I. B. 2018. Revitalisasi nilai-nilai Moral Keagamaan di era globalisasi melalui pendidikan agama. Dharmasmrti: Jurnal Ilmu Agama Dan Kebudayaan, 18(2): 5058.

Sunarso, A. 2020. Revitalisasi Pendidikan Karakter melalui Internalisasi Pendidikan Agama Islam (PAI) dan Budaya Religius. Jurnal Kreatif: Jurnal Kependidikan Dasar, 10(2): 155-169. 